\title{
Mirosław Soczówka
}

Instytut Geografii

Akademia Pedagogiczna w Krakowie

\section{Wykorzystanie technologii informacyjnej w nauczaniu - uczeniu się podstaw przedsiębiorczości}

Od czasu wprowadzenia komputerów do szkół w Polsce w połowie lat 80. XX w., urządzenia te i ich oprogramowanie stały się jednymi ze środków dydaktycznych stosowanych m.in. w nauczaniu - uczeniu się podstaw przedsiębiorczości. Postęp techniczny zaowocował jednak nowymi środkami dydaktycznymi ${ }^{1}$, w tym niemieszczącymi się w dotychczasowych klasyfikacjach stworzonych na potrzeby takich dyscyplin naukowych, jak dydaktyka geografii (np. Piskorz 1997). Od 1998 r. realizowane są programy modernizacyjne obejmujące kolejno każdą gminę, szkołę podstawowa, gimnazjum i liceum (szkoły ponadgimnazjalne). Były one finansowane przez Ministerstwo Edukacji Narodowej (dawniej kolejno: MENiS, MEiN), a od czasu wejścia Polski do UE są w trzech czwartych współfinansowane przez Europejski Fundusz Społeczny. W wyniku realizacji wspomnianych programów publiczne szkoły ponadgimnazjalne zostały wyposażone w pracownie komputerowe z dostępem do internetu (złożone z 15 komputerów dla uczniów), komputery w bibliotekach (po 4 sztuki) tworzące internetowe centra edukacji multimedialnej, wybrane programy komputerowe, a obecnie są wyposażane m.in. w komputery przenośne i projektory multimedialne, czyli tzw. mobilne zestawy multimedialne ${ }^{2}$. Znaczącą aktywność w zakresie tworzenia środków dydaktycznych z zakresu technologii informacyjnej (TI) przejawiają komercyjne wydawnictwa edukacyjne.

\section{Komputerowe programy edukacyjne i ich obudowa internetowa}

Część wydawnictw edukacyjnych, wykorzystując wyposażenie szkół w środki dydaktyczne z zakresu technologii informacyjnej, próbuje, za pomocą komputerowych programów edukacyjnych na płytach CD-ROM dołączanych do podręczników lub z nimi powiązanych, przyciągnąć większą liczbę klientów i zwiększyć efekty procesu nauczania - uczenia się podstaw przedsiębiorczości. W 2002 r. ukazał się program „Kariera”, dołączony do podręcznika „Przedsiębiorczość bez tajemnic” wydanego przez WSiP (Gregorczyk, Romanowska, Sopińska, Wachowiak 2002). Składa się on z kilku modułów. W module „Curriculum vitae” zamieszczono zasady pisania życiorysów, interaktywne ćwiczenie w ich tworzeniu oraz 5 przykładowych życiorysów do wydrukowania. W dziale „List motywacyjny” znajdują się rady, jak pisać listy motywacyjne, oraz 5 przykładowych listów do wydrukowania. W module „Rozmowa rekrutacyjna” przedstawiono rady, jak przygotować się do rozmowy rekrutacyjnej i jak się podczas niej zachowywać oraz interaktywną rozmowę z przyszłym pracodawca. W dziale „Testy” znajdują się informacje o testach

\footnotetext{
${ }^{1}$ Środki dydaktyczne zalecane do użytku szkolnego przez Ministerstwo Edukacji Narodowej w zakresie przedmiotów ogólnoksztatcacych, MEN, Warszawa, http://www.srodki-dydaktyczne.men.gov.pl/, 18.11.2006 r. ${ }^{2}$ Pracownie komputerowe dla szkót. Projekt na lata 2004-2006, MEN, Warszawa, http://www.men.gov.pl/ edu_infor/projekty_efs/pracownie.php, 18.11.2006 r.
} 
psychometrycznych, którym może zostać poddany kandydat do pracy, dotyczące ich rady oraz przykładowy interaktywny test psychometryczny. W module „Rób karierę!” użytkownik ma możliwość przejść procedurę rekrutacyjną (CV, rozmowa rekrutacyjna, test psychometryczny) do 4 wybranych zawodów. Program zawiera również demonstracyjną wersję obudowy internetowej podręcznika z przykładowymi modułami przeznaczonymi dla ucznia i nauczyciela, dostępną także w aktualnej, pełnej wersji na stronach serwisu internetowego WSiPnet (www.wsipnet.pl). W podręczniku umieszczono ikony odsyłające do obudowy internetowej. W obudowie internetowej, w części dla uczniów, każdy temat lekcji zawiera: informacje tekstowe ilustrowane interaktywnymi animacjami lub ćwiczeniami, ćwiczenia i zadania, a na zakończenie działu test interaktywny oraz odnośniki do wybranych stron internetowych. W części dla nauczyciela każdy temat lekcji zawiera: informacje tekstowe z celami kształcenia i zalecaną literaturą; odnośniki do wybranych stron internetowych oraz materiały dodatkowe w postaci projektów ćwiczeń dodatkowych, możliwych do pobrania projektów testów w formatach pdf i doc; a także foliogramy w formacie pdf. W obudowie część odnośników do stron internetowych jest już nieaktualna.

Mankamentem programu dla użytkowników nowoczesnych monitorów jest stała rozdzielczość 800 x 600 pikseli, z którą on pracuje. Program „Kariera” dołączany jest również do wydanego przez WSiP podręcznika do podstaw przedsiębiorczości dla zasadniczej szkoły zawodowej.

W 2002 r. ukazał się również program „Szansa dla interaktywnych”, dołączony do podręcznika „Szansa dla przedsiębiorczych” wydanego przez Wydawnictwo eMPi (Pietraszewski 2002). Dzięki wykonaniu interfejsu programu w języku HTML, automatycznie dostosowuje się on do aktualnej rozdzielczości ekranu. Treści merytoryczne tworzące program „Szansa dla interaktywnych” są pogrupowane według rozdziałów w podręczniku. Oprócz zagadnień merytorycznych w postaci tekstów, rycin, interakcji i filmów dydaktycznych, w każdym dziale zamieszczono serię rysunków satyrycznych „Na wesoło o ...” oraz krótkie interaktywne testy z zadaniami wyboru wielokrotnego. Zawartość programu uzupełniają: wykaz kilkuset przydatnych adresów internetowych, „Kalkulator przedsiębiorczego” i „Słowniczek przedsiębiorczego” zawierający ponad 600 haseł oraz grę ekonomiczną pt. „Szansa na zysk”. W serwisie internetowym wydawnictwa dostępne są aktualizacje danych statystycznych do podręcznika „Szansa dla przedsiębiorczych” oraz aktualizacja 2 tabel do zeszytu ćwiczeń „Szansa dla aktywnych”. Mogą one być drukowane z poziomu strony internetowej. Część danych i adresów internetowych zamieszczonych w programie jest już zdezaktualizowana, ale jest możliwość ściąnięcia i zainstalowania pliku z aktualizacją treści podręcznika i płyty CD-ROM, która funkcjonuje jako osobny program. Wydawnictwo eMPi ${ }^{2}$ oferuje również podręcznik pt. „Elementarz życia gospodarczego” (Pietraszewski 2001) wraz z płytą CD-ROM pt. „Dociekliwy na rynku” do modułu „Wychowanie do aktywnego udziału w życiu gospodarczym” w przedmiocie wiedza o społeczeństwie w gimnazjum. Ze względu na czas powstania programu, $w$ serwisie internetowym firmy jest dostępna jego aktualizacja. Oprócz nieaktualności danych wynikającej z czasu powstania programów Wydawnictwa eMPi ${ }^{2}$, wadą części ich stron jest to, że wymagają przewijania zawartości ekranu w pionie. Wyniki badań pokazują, że około połowy użytkowników komputerów czyni to rzadko lub nie czyni wcale, tym samym część zawartości programów jest dla nich niedostępna.

W 2005 r. Fundacja Młodzieżowej Przedsiębiorczości wydała uaktualnioną wersję podręcznika podstaw przedsiębiorczości pt. „Ekonomia stosowana”, wzbogaconą o płytę CD-ROM (Belka 2005). Pod tym samym tytułem po raz pierwszy wydano również zeszyt ćwiczeń wraz z płytą CD-ROM (Neneman 2005). W obu programach zawartość jest uporządkowana w modułach odpowiadających rozdziałom w podręczniku i zeszycie ćwiczeń. W każdym module jest kilka części. Program dołączony do podręcznika zawiera treści merytoryczne w postaci tekstów, interaktywnych rycin, wykładów multimedialnych, filmów, interaktywnych ćwiczeń itp. Do programu 
dołączono dwa osobne moduły zatytułowane „Słownik” i „Być przedsiębiorczym”. Ten ostatni moduł poświęcony jest rozwijaniu wiedzy i umiejętności z zakresu szeroko rozumianej komunikacji interpersonalnej. Na płycie CD-ROM dołączonej do zeszytu ćwiczeń zamieszczono wiele interaktywnych ćwiczeń z zadaniami: wyboru wielokrotnego, typu prawda-fałsz, na przeciaganie itp. Pracując z programem, uczeń nie ma możliwości udzielenia błędnej odpowiedzi, gdyż takie nie są akceptowane. Ćwiczenia w poszczególnych rozdziałach często kończą się krzyżówką związaną tematycznie z rozdziałem. Do programu ćwiczeniowego dołączono osobny moduł - słownik.

W czwartym wydaniu podręcznika podstaw przedsiębiorczości Wydawnictwa Nowa Era (Makieła, Rachwał 2005) zamieszczono płytę CD-ROM przygotowaną wspólnie z Wydawnictwem Young Digital Poland (Śrutowska 2006). Wydawnictwo Young Digital Poland ma kilkuletnie doświadczenie w konstruowaniu podręczników multimedialnych, m.in. z serii EduROM i EduLAN (Soczówka 2002). Program ma jasne tło, zastosowano w nim ciepłe barwy, funkcjonalne rozwiązania zapewniające przemieszczanie się między stronami, ułatwiające prezentację treści oraz interakcję z użytkownikiem. Na przykład: rozbudowane animacje mogą być odtwarzane w całości, zatrzymane w trakcie odtwarzania w dowolnym momencie lub odtworzone w części w postaci stanowiącej pewną całość wartą powtórzenia lub szczegółowego omówienia. Program składa się z 7 modułów odpowiadających rozdziałom w podręczniku. Przeciętny moduł składa się z kilkunastu stron (a te często dodatkowo z 2 lub 3 podstron), z których początkowe zawierają głównie treści merytoryczne. Mają one postać krótkich tekstów, rycin, wykresów, filmów, animacji, symulacji, wykładów multimedialnych itp. Ostatnie strony to ćwiczenia: wiele interaktywnych zadań wyboru wielokrotnego i zadań typu prawda-fałsz, których rozwiązywanie polega na zaznaczaniu, przeciąganiu lub łączeniu ze sobą różnych elementów. Uzupełnieniem omówionych modułów jest moduł „Druki urzędowe”. Zamieszczone z nim druki użytkownik może wypełniać. Program zawiera również moduły dodatkowe, ułatwiające korzystanie z niego: „Słowniczek” i „Szukaj” (umożliwiający wybór poszukiwanych treści z alfabetycznej listy). Inny sposób wyszukiwania polega na wpisaniu kodu z podręcznika na stronie startowej programu, w specjalnym polu edycyjnym, a następnie naciśnięciu klawisza ,enter”. Pojawia się wówczas strona tytułowa danej lekcji oraz kilka stron z treściami merytorycznymi i ćwiczeniami. Warto podkreślić, że autorzy omawianego programu również $\mathrm{w}$ innych publikacjach pakietu edukacyjnego często zalecają wykorzystywanie technologii informacyjnej w nauczaniu - uczeniu się podstaw przedsiębiorczości. W poradniku metodycznym (Makieła, Rachwał 2005) wskazują programy komputerowe, które mogą być wykorzystywane na lekcjach podstaw przedsiębiorczości, i zamieszczają katalog stron www przydatnych na tego typu zajęciach. W scenariuszach kilkunastu zajęć edukacyjnych (Bachta 2003) wskazują możliwości wykorzystania komputera i internetu, m.in. serwisu wydawnictwa Nowa Era, w którym są dostępne pliki zawierające aktualne wersje ważnych aktów prawnych.

Od jesieni 2005 r. nauczycielom podstaw przedsiębiorczości udostępniono nowy rodzaj komputerowych programów edukacyjnych, powiązanych z podręcznikami, lecz sprzedawanych jako odrębny produkt. Są to plansze interaktywne (Gregorczyk, Majewski 2005) przygotowane przez WSiP, które są rozszerzoną elektroniczną wersją publikacji „Przedsiębiorczość bez tajemnic. Zestaw foliogramów dla nauczycieli szkół ponadgimnazjalnych”. Program zawiera 54 plansze obejmujące treści z następujących grup tematów: psychologiczne i socjologiczne uwarunkowania przedsiębiorczości (6 plansz), makrouwarunkowania przedsiębiorczości (11 plansz), przedsiębiorczość w sferze życia zawodowego (17 plansz), przedsiębiorczość w rodzinie (12 plansz), zachowania przedsiębiorcze na rzecz środowiska lokalnego (6 plansz), pracownik w przedsiębiorstwie (2 plansze). Różnią się one od tradycyjnych foliogramów obecnością elementów multimedialnych i interakcyjnych. Stanowią je uruchamiane przez użytkownika krótkie komentarze 
dźwiękowe, interaktywne opisy tekstowe prawie wszystkich rycin i schematów, które można włączyć i wyłączyć jednym kliknięciem myszy. Ostatnia ze wskazanych funkcji umożliwia projektowanie i prowadzenie lekcji z programem w sposób zmierzający do odkrycia wyłączonego elementu, jego związków z innymi elementami schematu itp. Jest bardzo przydatna do kontroli wiedzy uczniów. Aby wybrać jedną z plansz, można skorzystać z 4 sposobów ich sortowania. Program umożliwia również sprawdzenie wiedzy uczniów w inny sposób, dzięki osobnemu modułowi testowemu, w którym zebrano po dwa pytania testowe wielokrotnego wyboru dotyczące każdej planszy. Użytkownik może określić zakres tematyki objętej testem, a po jego wykonaniu przejrzeć wyniki z automatycznie wygenerowanym wskazaniem poprawnych odpowiedzi, a nawet wydrukować oceniony test. Wady tego programu to długi, trwający około 40 sekund czas uruchamiania, niemożność sortowania plansz według działów w podręczniku, a także często zbyt mała liczba plansz przydatnych na pojedynczej lekcji.

Do prowadzenia lekcji z omawianym programem w pracowni przedmiotowej można wykorzystać dostępne w coraz większej liczbie szkół tzw. mobilne zestawy multimedialne. Inne rozwiązanie to lekcja w szkolnej pracowni komputerowej. Ta druga możliwość jest dostępna dzięki dostosowaniu programu do pracy w lokalnej sieci komputerowej i udzieleniu przez wydawnictwo licencji dla 10 stanowisk. Niestety, liczba udzielonych licencji nie została dostosowana do przeciętnej liczby komputerów w pracowniach informatycznych w szkołach ponadgimnazjalnych (co najmniej 15 sztuk). Najpóźniej po dwutygodniowym okresie testowania program należy zarejestrować za pośrednictwem internetu, aby móc z niego korzystać.

\section{Programy o charakterze ogólnym oraz pliki tworzone przez nauczycieli i uczniów}

Niektóre programy komputerowe nie zawierają co prawda treści z zakresu podstaw przedsiębiorczości, ale mogą być przydatne w ich pozyskiwaniu, archiwizowaniu i prezentacji. Brak łączy internetowych w większości pracowni przedmiotowych, ich ograniczona przepustowość w części tych pracowni, okresowe znikanie niektórych serwisów, np. na czas konserwacji serwera, oraz zmiany zawartości tych serwisów powodują, że nauczyciel może być zainteresowany ich archiwizowaniem. Zdaniem autora niniejszego artykułu najlepszym programem do tego celu jest HTTrack Website Copier 3.40-2 (www.httrack.com). Istotną zaletą części programów komputerowych jest możliwość integracji przez nie różnych treści. Jednym z nich jest program StarTree Studio v. 3.0 firmy Inxight Software (http://pedagogika.net), który umożliwia tworzenie swoistych interaktywnych map myśli, złożonych z elementów, które za pomocą wpisanych w nie ścieżek dostępu pozwalają szybko uruchomić dowolne pliki znajdujące się na twardym dysku komputera, w stacjach roboczych lub w internecie. Taka konstrukcja programu, w powiązaniu z mobilnym zestawem multimedialnym, umożliwia nauczycielowi dostosowanie treści wykorzystywanych na lekcji do poziomu klasy i przebiegu lekcji, która nie zawsze jest zgodna z pierwotnym planem.

W nauczaniu - uczeniu się podstaw przedsiębiorczości, zwłaszcza z użyciem mobilnego zestawu multimedialnego, mogą być stosowane programy typu Office, np. pakiety biurowe Microsoft Office bądź bezpłatny OpenOffice 2.0, zawierające m.in. programy do edycji tekstów, arkusze kalkulacyjne oraz programy do tworzenia i wyświetlania prezentacji multimedialnych. Umiejętność tworzenia różnorodnych tekstów jest dziś niezbędna niemal w każdej pracy, a wykorzystanie arkuszy kalkulacyjnych znacznie ułatwia obróbkę danych liczbowych, w tym finansowych. Za stosowaniem prezentacji multimedialnych przygotowanych samodzielnie przez nauczyciela przemawia niewielka liczba gotowych do użycia w szkole materiałów w postaci elektronicznej, zawierających treści z zakresu podstaw przedsiębiorczości, np. informacji społeczno-gospodarczych, zwłaszcza dotyczących regionu, w którym znajduje się szkoła (Soczówka, Uliszak 2004). Przeciw wykonywaniu przez uczniów lub nauczycieli i stosowaniu prezentacji multimedialnych 
na lekcjach przemawia głównie ich pracochłonność oraz możliwość powstawania i upowszechniania błędów merytorycznych bądź metodycznych, np. w ułożeniu treści. Prezentacje multimedialne i witryny internetowe stwarzająjednak szansę na aktywizację przynajmniej części uczniów wokół tworzenia i udostępniania innym osobom efektów projektów edukacyjnych oraz na związaną z ich tworzeniem korelację międzyprzedmiotową realizowaną przez nauczycieli podstaw przedsiębiorczości i informatyki, wzorowanej na podobnej aktywności nauczycieli geografii oraz technologii informacyjnej (Rokicki, Kopaczyński 2004). Uczniowie mogą wówczas rozwijać umiejętności wyszukiwania, segregowania, oceniania informacji oraz pracy w grupach, w zbyt małym stopniu rozwijane na tradycyjnych lekcjach podstaw przedsiębiorczości.

Dość liczna grupa programów komputerowych ułatwia tworzenie „map” myśli w postaci graficznej. Aby znaleźć o nich informacje i odpowiednie pliki instalacyjne (najczęściej w wersji trial - działające bezpłatnie przez 3-4 tygodnie) wystarczy w dowolnej przeglądarce internetowej wpisać hasło „Mind Mapping”. Niektóre z takich programów, np. FreeMind 0.80, są bezpłatne. Dzięki takim programom można urozmaicić wykorzystywanie wskazanej metody kształcenia.

Osobną grupę, słabo dotychczas reprezentowaną w szkołach ze względu na wysokie ceny zestawów, są programy do obsługi tablic interaktywnych. Przykładem jest program StarBoard Software 6.2 (2005), opracowany przez firmę Hitachi dla tablicy interaktywnej StarBoard F-75. W Polsce są one dystrybuowane przez WSiP. Tablica interaktywna i jej oprogramowanie nie zawierają żadnych treści z podstaw przedsiębiorczości, umożliwiająjedynie, za pomocą komputera i projektora multimedialnego, prezentację zawartości innych programów, filmów i źródeł internetowych. Pozwalają ponadto na ich uzupełnianie o notatki użytkowników, archiwizowanie i drukowanie. Tablice interaktywne mogą być wykorzystywane jako mobilne lub stacjonarne; drugie rozwiązanie jest znacznie mniej skomplikowane ze względu na łatwiejszą obsługę.

\section{Internet w nauczaniu - uczeniu się podstaw przedsiębiorczości}

Oprócz korzystania z opisanych wyżej obudów internetowych podręczników i dołączanych do nich płyt CD-ROM do podstaw przedsiębiorczości, można sięgnąć do internetu. Znajduje się w nim wiele serwisów zawierających wartościowe informacje. W nauczaniu - uczeniu się podstaw przedsiębiorczości często wykorzystuje się dane statystyczne. W przypadku aktualizacji i rozszerzania danych dotyczących Polski warto korzystać z serwisu GUS (www.stat.gov.pl). Oprócz różnorodnych danych ogólnokrajowych zawiera on dużo danych dotyczących regionów. Są to przede wszystkim dane Banku Danych Regionalnych. Tego typu informacje są zbyt rzadko wykorzystywane na lekcjach podstaw przedsiębiorczości. Należy jednak pamiętać, że ludność Polski jest mało mobilna przestrzennie, a miejsce urodzenia ucznia jest często miejscem jego przyszłej działalności zawodowej. Dlatego dokładna charakterystyka tego regionu, zwłaszcza w zakresie szybko zmieniających się danych społeczno-gospodarczych, jest możliwa (Soczówka, Uliszak 2004), a będzie bardzo użyteczna. Godnym polecenia serwisem edukacyjnym jest Portal Edukacji Ekonomicznej NBPortal.pl, działający od 2003 r. Jest on dostępny w internecie lub w postaci 5 archiwów off-line na płytach CD-ROM. Te ostatnie powstawały od 2003 r., a obecnie 2 ostatnie (płyta 4 - Edycja MONETA, płyta 5 - Edycja BANKNOT) są dostępne dla wszystkich chętnych darmo w centrali i oddziałach terenowych NBP. Portal jest podzielony na kilka działów, w trzech zakładkach. W zakładce Na poczq̨tek są dostępne m.in. działy Bloki tematyczne, Porady, Zbiory wiedzy; w zakładce Centrum wiedzy mieszczą się działy E-learning, Prezentacje, Gry i Rozrywka, a w zakładce Szkolny NBPortal.pl dostępne są m.in. działy Centrum nauczyciela i Centrum ucznia. Uzupełniają je narzędzia w postaci Stownika Ekonomicznego PWN, Wirtualnej Biblioteki i Kalkulatorów. Podstawową część portalu tworzy 7 e-lerningowych kursów multimedialnych, zatytułowanych: Ekonomia wokół nas, Euro coraz 
bliżej, Analiza finansowa firmy, Kredyty i Ty, Historia monetarna Polski, Bankowość oraz Grosz do grosza, czyli jak inwestować. W wersji on-line są one dostępne dla zarejestrowanych użytkowników w postaci ponad 200 godzin lekcji zawierających wykłady multimedialne, w których wykorzystywane są liczne animacje, ilustracje i krótkie filmy. Są one często przeplatane ćwiczeniami sprawdzającymi i utrwalającymi wiedzę.

W 2005 r. badano stan edukacji z zakresu podstaw przedsiębiorczości w wybranych szkołach oraz opinie nauczycieli tego przedmiotu, doradców metodycznych, dyrektorów szkół oraz uczniów (Szmulczyńska 2006). W wyniku porównania tych opinii z ofertą opisywanego portalu stwierdzono, że należy położyć większy nacisk na tematy dotyczące: poszukiwania pracy, planowania i podejmowania działalności gospodarczej, rynku pracy i bezrobocia. Można natomiast zredukować treści poświęcone na mało popularne wśród uczniów zagadnienia: etykę w biznesie, rolę banków w gospodarce i planowanie budżetu gospodarstwa domowego.

\section{Podsumowanie}

Ze względu na duże obciążenie szkolnych pracowni internetowych w szkołach ponadgimnazjalnych, najlepsze warunki do nauczania podstaw przedsiębiorczości z wykorzystaniem technologii informacyjnych istnieją w szkołach dysponujących kilkoma pracowniami, z których jedna może być używana głównie do nauczania przedmiotów innych niż informatyka (Uczkiewicz 2005). Istniejąjuż projekty i przykłady realizowanych w takiej pracowni lekcji (Kulikowska 2005). Jeżeli ten warunek nie jest spełniony, a szkoła ma jeden (lub więcej) z coraz powszechniej dostępnych mobilnych zestawów multimedialnych, to najlepszym miejscem do realizacji omawianego sposobu nauczania jest pracownia przedmiotowa. Aby się do tego nadawała, powinna mieć dobre zaciemnienie, miejsce na zamontowanie ekranu lub ekran zamontowany na stałe oraz doprowadzenie łącza internetowego. Niezbędne są również wartościowe programy. Przegląd komputerowych programów edukacyjnych dołączanych do podręczników postaw przedsiębiorczości lub z nimi związanych prowadzi do wniosku, że programy powstałe później są lepsze pod względem merytorycznym. Zastosowane w nich rozwiązania interfejsu oraz sposoby przedstawiania treści są bardziej przyjazne, dzięki interaktywności zwiększają zaangażowanie użytkownika w obsługę programu (aktywizacja) i ułatwiają poznanie oraz omówienie rozbudowanych filmów i animacji.

W celu poprawy efektów nauczania - uczenia się podstaw przedsiębiorczości z wykorzystaniem mobilnego zestawu multimedialnego, należy spełnić kilka warunków. Przy projektowaniu komputerowych programów edukacyjnych należy pamiętać o ograniczonej do 4-6 liczby stron z treściami merytorycznymi, które można, odpowiednio obudowane metodycznie, wykorzystać w ciagu jednej lekcji. Programy te należy projektować wraz podręcznikami, zeszytami ćwiczeń i ich obudową dydaktyczna, tak aby były wzajemnie w jak największym stopniu powiązane i skorelowane treściowo. Programy edukacyjne powinny móc pracować w 2 trybach lub być tworzone w postaci odrębnych wersji dla uczniów i nauczycieli. W tych ostatnich należy zamieszczać nieco mniej treści merytorycznych, ułożonych w sposób ułatwiający ich wykorzystanie na lekcji. W komputerowych programach edukacyjnych należy stosować bardziej kontrastowe barwy, by zwiększyć czytelność. Ponieważ korzystanie z treści z zakresu podstaw przedsiębiorczości w postaci elektronicznej jest bardziej czasochłonne niż korzystanie z treści zaprezentowanych tradycyjnym drukiem, a bywa mniej czytelne dla odbiorców niż podręcznik, należy dążyć do zamieszczania w tych programach i plikach głównie treści w postaciach niedostępnych lub rzadkich w tradycyjnych środkach dydaktycznych, czyli różnego rodzaju elementów interaktywnych, animacji, symulacji, filmów itp., a nie w postaci ciagłego tekstu do czytania, gdyż funkcję tę lepiej spełnia tradycyjna książka. Pozostałe elementy powinny być zamieszczane rzadziej, ale prezentowane w postaci pełnoekranowej lub do niej zbliżonej. Ze względu na trudności 
praktyczne w wykorzystywaniu mobilnych zestawów multimedialnych (Soczówka 2006), warto je zastapić przez rozwiązania stacjonarne. Powinny również nastąić zmiany w zakresie realizowanych treści merytorycznych, np. polegające na wprowadzeniu zajęć z zakresu funkcjonowania e-biznesu (Uczkiewicz 2005), oraz w używanych metodach kształcenia, polegające m.in. na częstszym stosowaniu metod aktywizujących (np. metody projektów).

\section{Literatura}

1. Bachta A. i in., 2003, Podstawy przedsiębiorczości. Scenariusze zajęć edukacyjnych, Nowa Era, Warszawa

2. Belka M. (red.), 2005, Ekonomia stosowana. Podręcznik do podstaw przedsiębiorczości dla liceów ogólnoksztatcacych, liceów profilowanych i techników, Fundacja Młodzieżowej Przedsiębiorczości, Warszawa

3. Gregorczyk S., Majewski B., 2005, Podstawy przedsiębiorczości. Plansze interaktywne dla nauczycieli szkót ponadgimnazjalnych, (program na płycie CD-ROM), WSiP, Warszawa

4. Gregorczyk S., Romanowska M., Sopińska M., Wachowiak P., 2002, Przedsiębiorczość bez tajemnic. Podręcznik do nauczania podstaw przedsiębiorczości dla liceum ogólnoksztatcacego, liceum profilowanego i technikum. Ksztatcenie w zakresie podstawowym, WSiP, Warszawa

5. Kulikowska M., 2005, Możliwość wykorzystania komputera na zajęciach podstaw przedsiębiorczości na przykladzie lekcji nt. podatków pośrednich (scenariusz lekcji) [w:] seria: Przedsiębiorczość - Edukacja nr 1, Przedsiębiorczość a współczesne wyzwania cywilizacyjne, Z. Zioło, T. Rachwał (red.), Wyd. MiWa, Kraków

6. Makieła Z., Rachwał T., 2005, Podstawy przedsiębiorczości. Poradnik metodyczny. Liceum ogólnokształcqce, liceum profilowane i technikum. Ksztatcenie ogólne w zakresie podstawowym, wyd. 3, Nowa Era, Warszawa

7. Makieła Z., Rachwał T., 2005, Podstawy przedsiębiorczości. Podręcznik dla liceum ogólnokształcacego, liceum profilowanego i technikum, Nowa Era, Warszawa

8. Neneman J., 2005, Ekonomia stosowana. Zeszyt ucznia z ćwiczeniami i plyta CD do podstaw przedsiębiorczości. Dla uczniów liceów ogólnokształcacych, liceów profilowanych i techników, Fundacja Młodzieżowej Przedsiębiorczości, Warszawa

9. Pietraszewski M., 2001, Elementarz życia gospodarczego, Wyd. eMPi², Poznań

10. Pietraszewski M., 2002, Szansa dla przedsiębiorczych. Podręcznik podstaw przedsiębiorczości dla liceów i techników, Wydawnictwo eMPi², Poznań

11. Rokicki R., Kopaczyński B., 2004, Atrakcyjność turystyczna powiatu wschowskiego. Metoda projektu edukacyjnego, „Geografia w Szkole”, r. 57, nr 1

12. Soczówka M., 2002, Polskie podręczniki multimedialne do nauczania-uczenia się geografii i przyrody [w:] Interdyscyplinarne nauczanie przedmiotów przyrodniczych, A. Kaszubski (red.), Pracownia Dydaktyki Chemii Instytutu Chemii UMK w Toruniu, Toruń

13. Soczówka M., 2006, Mobilny zestaw multimedialny w nauczaniu-uczeniu się geografii [w:] Komputer w edukacji. 16 Ogólnopolskie Sympozjum Naukowe, J. Morbitzer (red.), Wydawnictwo Naukowe AP w Krakowie, Kraków

14. Soczówka M., Uliszak R., 2004, Możliwości wykorzystania Internetu do nauczania-uczenia się o regionie ucznia [w:] Polska dydaktyka geografii jako nauka i sztuka, Wydawnictwo Naukowe AP, Kraków

15. Szmulczyńska B., 2006, Zapotrzebowanie środowiska szkolnego w zakresie edukacji ekonomicznej a oferta edukacyjna Portalu Edukacji Ekonomicznej Narodowego Banku Polskiego - NBPortal.pl [w:] seria: Przedsiębiorczość - Edukacja nr 2, Rola przedsiębiorczości w podnoszeniu konkurencyjności społeczeństwa i gospodarki, Z. Zioło, T. Rachwał (red.), Nowa Era, ZPiGP IG AP, Kraków

16. Śrutowska D., 2006, Wykorzystanie multimediów w nauczaniu przedsiębiorczości (na przykładzie multimedialnego CD-ROM-u Wydawnictwa Nowa Era pt. Podstawy przedsiębiorczości) [w:] seria: Przedsiębiorczość - Edukacja nr 2, Rola przedsiębiorczości w podnoszeniu konkurencyjności społeczeństwa i gospodarki, Z. Zioło, T. Rachwał (red.), Nowa Era, ZPiGP IG AP, Kraków 
17. Uczkiewicz P., 2005, Technologia informacyjna a przedsiębiorczość w szkole ponadgimnazjalnej [w:] seria: Przedsiębiorczość - Edukacja nr 1, Przedsiębiorczość a współczesne wyzwania cywilizacyjne, Z. Zioło, T. Rachwał (red.), Wyd. MiWa, Kraków

18. Zarys dydaktyki geografii, 1997, S. Piskorz (red.), wyd. 2 zmienione, Wydawnictwo Naukowe PWN, Warszawa

\section{The Use the Information Technology for Teaching Basis of Entrepreneurships}

This paper presents results of review and didactical analysis of some multimedia discs published with handbooks for "Basis of Entrepreneurships" for high schools, their internet casing and chosen thematic internet services. On the base of his own research the author presents some changes needed to better use the information technology in schools especially for teaching and learning "Basis of Entrepreneurships". 